\title{
Checklist for development of faculty advisory committee orientation materials
}

\author{
Prepared by the ACRL Task Foree on Faculty Advisory \\ Committee Orientation Material
}

Florence Doksansky, Chair

\section{Make sure your advisory committee gets a good orientation}

\section{to the library.}

1

$t$ this time of financial uncertainty and change in higher education, librarians face a critical need to educate faculty on library and information policy issues of both local and national significance. An open exchange of information about the library should be established with faculty and administrators, since the understanding and support of library needs within the academic community is essential to the well-being of libraries. This goal can be met most effectively through the establishment of formal, open channels of communication.

One means of enhancing campus communication is the establishment of a Faculty Advisory Committee (FAC) to the library. This group acts as an informed body of library users to support and assist the library. It should be made of faculty representing the major academic subject areas: humanities, social sciences, life and physical sciences, and others as appropriate. Students should also be represented.

The following general guidelines are designed to assist individual libraries in effectively working with Faculty Advisory Committees, by establishing guidelines that are appropriate within their own institutions.

\section{Development and implementation}

When developing guidelines and materials to orient FACs, each library will want to consider:

- the mission of the parent institution

- the type of committee structure that exists
- who appoints the committee

- the reporting structure of the committee

- the amount of authority vested in the committee

- the relationship the committee has had with the library and the institution.

\section{Orientation guidelines}

Materials. Information packets should be developed by the library staff and sent to the members of the FAC in advance of its first meeting. Materials in these orientation packets should include general information about the library's mission, services, and collections, including (but not limited to) organization charts, strategic planning documents, budgetary requests or reports produced during the past two years, library newsletters, policy statements, library guides, etc.

Orientation. The committee members should be given a thorough orientation to the library as an organization, to its key personnel, and to the role of the library within the institution. The committee should receive an introduction to the budget of the library and how it meets the needs of the academic community. Since a thorough knowledge of the library's physical plant is necessary for an understanding of space, planning, and service issues, it may be useful for the committee to tour the library and its various satellite facilities.

Issues. The FAC should be informed of the library's plans and concerns as well as of library and information policy issues that are of both local and 
national significance. Suggested agenda items include: technology, budgetary issues such as serial commitments and prices, access to government information, electronic information products, shared resources agreements, building renovation plans and space needs, technical processing issues and retrospective conversion plans, collection development issues, library use instruction programs, online catalog plans, staffing levels, preservation programs, fundraising and developing activities, and library friends groups.

In summary, the major goal of any orientation program for FACs should be made to make committee members feel that they have an important role in celebrating library successes as well as addressing libraryconcerns. This can be accomplished by educating committee members about the library as an organization. Only through the free flow of information about the library will members of the FAC "buy in" to the tasks at hand, and remain "friends of the library" after their term is complete.

Ed. note: The task force submitted its final report to the ACRL Board at the 1991 Annual Conference. Members of the task force were David Ferriero, Massachusetts Istitute of Technology; Brigid Welch, Association of Research Libraries; and Florence Doksansky, Brown University, chair.

\section{Latin American seminar on official publications makes recommendations}

Librarians from 19 countries participated in the Latin American Seminar on Official Publications held in Mexico City from June 10-12, 1991. The meetings were held in the Biblioteca Nacional, a part of the Institutode Investigaciones Bibliograficas (IIB) on the campus of the Universidad National Automona de Mexico (UNAM). This is the fourth seminar sponsored by the International Federation of Library Associations and Institutions (IFLA) Government Information and Official Publications Section.

Presentations on official publications were made by individuals from the 17 Latin American countries invited to attend (Argentina, Brazil, Chile, Colombia, Costa Rica, Cuba, Ecuador, Guatemala, Honduras, Mexico, Nicaragua, Panama, Peru, Republica Dominicana, El Salvador, Uruguay, Venezuela) and in the English speaking Caribbean. The overview was followed by other papers that examined the definition of official publications, the need to study these materials, the use of official publications, bibliographic control of these materials, publications of the United Nations and the World Bank, and teaching about official publications in library schools.

A series of recommendations dealing with access, regulation, editorial policies, and dissemination were developed. Latin American governments were asked to adopt measures to strengthen the national libraries and other depository libraries so these may fulfill their responsibilities of acquiring, preserving, organizing, and disseminating the national official record, including state, provincial, departmental, municipal, and other publications. Government organizations charged with the plan- ning of information policies were requested to regulate the production of official publications. Government agencies in general were asked to establish directives for an editorial policy which would include what, how, when, how much, and for whom to publish and that these consider elements of bibliographic control such as cataloging-in-source, ISBN, ISSN, etc. National libraries or depository institutions of official publications were asked to create the mechanisms to facilitate the fulfillment and dissemination of the legal deposit laws and related regulations, and to implement international standards for bibliographic description and access.

Following considerable discussion about teaching official publications in library schools, professional associations and library schools were asked to promote the education and training of human resources for the management of official publications and research on production, wise, and availability of official publications. IFLA was asked to recommend to international organizations that periodic short courses for personnel who manage collections of official publications be offered. IFLA was also asked to sponsor a research project and bibliography to determine the state-of-the-art of official publications in Latin America.

The seminar, organized by Rosa Maria Fernandez de Zamora of IIB, received assistance from IFLA's Government Information and Official Publications Section and IFLA's program on Advancement of Librarianship in the Third World, the Organization of American States, and the Biblioteca Nacional of UNAM in Mexico. Plans are topublish the proceedings of the seminar.-Barbara J. Ford, Virginia Cominonwealth University 